\title{
5. THE INNOVATIVE PRAXEOLOGY: SUGGESTIONS FOR IMPLEMENTING IN ARTISTIC EDUCATION
}

Tatiana Bularga ${ }^{268}$

\begin{abstract}
The process of artistic perception in instructive and formative actions is identified with the educative action itself. In this process the considerable weight rests on the participative state kid to the design, development and evaluation/self-evaluation (through prescription of individual behavioural maps, anticipating practical actions, varying operations, performing the tasks by choosing the optimal variants for solving) and the dynamics of professional competence of teachers to achieve gradually the theoretical design process and practical actuating, by identifying educational content and valuable actions, diagnosing the individual resources, planning, forming hypotheses, sequential and final evaluation. In our statements we proceed from the reality that the artistic activity differs much from other human activities through its ontological specifics, which requires taking into account the opportunities and challenges that arise in individual potential manifestation of the child, act that expresses by transposing the theoretical prescriptions into practical actions indisputable by the presence of emotional-affective reactions, by developing projects and logistical maps of action, is not waiting for certain stimuli coming from outside, but by enhancing the artistic intentions and decisions of child - subjects of education.
\end{abstract}

Key words: artistic education, proactive behaviour, success of personality, innovative and artistic praxeology, artistic action of teacher, artistic action of pupil, creativity, actional freedom, teacher's and pupils' proactive style, actional options

\section{Introduction}

The lasting study of practice in the artistic education in the Republic of Moldova proves us quite convincingly that between the artistic theory and praxeology there is a significant discrepancy, which negatively influences the management for the implementation of an innovating praxeology, meaning of training through innovation. In the field of building personality through art, we notice that practice does not meet in the least the technological necessary specific to processes of reception-understanding-creation of works of art. In this educational area the undertaking for the optimization of the theory-practice report obtains instructive-formative valencies and of additional artistic development, due to the principles of creation/recreation-reception of artistic products, which foresee that the work of art exists only in the process of its interpretationvisualisation-audition - process which integrates the mental action of the author of creation, considered conventionally as a theoretical one, with the reception action and, at the same time, being considered a practical one. The process of artistic reception within instructive-formative actions is identified with the

\footnotetext{
268 Associate Professor PhD., „Alecu Russo” State University from Bălţi, Republic of Moldavia, email: tatianabularga@rambler.ru
} 
educational action itself. In this process, a significant weight falls on the participatory state of the pupil/student to the action of designing, carrying out and assessment/self-assessment (by assigning individual behavioural maps, anticipation of practical actions, variety of operations, execution of tasks by choosig optimal solution variants) and of the dynamics of professional competence of the teaching staff member of gradually executing the designing process (theoretical) and acting one (practical), by identifying educational contents and value actions, diagnosis of individual resources, planning, building hypotheses, sequential and final assessment. (Tab. no. 1)

\begin{tabular}{|c|c|c|c|c|c|}
\hline Variables & \multicolumn{2}{|c|}{ Real score } & $\begin{array}{c}\text { Score in } \\
\text { percentage }\end{array}$ & \multicolumn{2}{c|}{ Average mean } \\
\cline { 2 - 5 } & Grade $1^{\text {st }}-4^{\text {th }}$ & Grade $5^{\text {th }}-8^{\text {th }}$ & Grade $1^{\text {st }}-4^{\text {th }}$ & Grade $5^{\text {th }}-8^{\text {th }}$ & \\
& & & & & \\
\hline
\end{tabular}

\begin{tabular}{|c|c|c|c|c|c|c|}
\hline \multirow{3}{*}{ 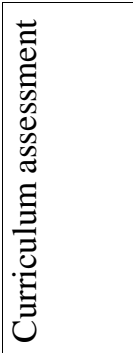 } & Theoretical items & 67 & 84 & 43,5 & 52,8 & 48,1 \\
\hline & Practical items & 79 & 64 & 51,2 & 40,2 & 45,7 \\
\hline & Integration items & 8 & 11 & 5,2 & 6,9 & 12,1 \\
\hline \multirow{3}{*}{ 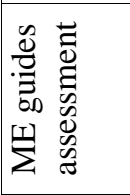 } & E/S & 31 & 34 & 27,0 & 29,8 & 28,4 \\
\hline & $\mathrm{M} / \mathrm{E}$ & 57 & 53 & 50,0 & 46,4 & 48,2 \\
\hline & $\mathrm{E} / \mathrm{I}$ & 26 & 27 & 22,8 & 23,6 & 23,2 \\
\hline \multirow{4}{*}{ 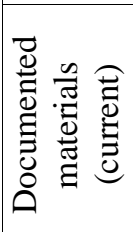 } & Articol & \multicolumn{2}{|c|}{67} & \multicolumn{2}{|c|}{58,7} & \\
\hline & Books & \multicolumn{2}{|c|}{26} & \multicolumn{2}{|c|}{22,8} & \\
\hline & Report & \multicolumn{2}{|c|}{6} & \multicolumn{2}{|c|}{5,2} & \\
\hline & Other sources & \multicolumn{2}{|c|}{88} & \multicolumn{2}{|c|}{77,1} & \\
\hline
\end{tabular}

\section{Discussions}

As efficiency criteria the following are identified:

1. methodological (planned and executed with the taking into consideration the application of technologies and efficiency strategies);

2. psychological (with taking into account psychical factors, meaning the internal content of personality);

3. physiological (pupil/student - subject/object of education is a being endowed with psychical/spiritual capacities, but also with physical capacities, which involves the promotion of a binomial educational policy with an efficient connection of both forms of existence);

4. pedagogical (the usage of efficient modern principles and technologies of management with the educational-formative process);

5. aesthetic (all the cognitive-formative steps must be executed based on classical and contemporary knowledge); 
6. praxeological (didactic actions of the teacher and artistic actions of the pupil/student must be instrumented and methodologically founded and executed with a high practical effect);

7. axiological (education if centred on value and integrated);

8. sociological (artistic education constitutes a microsystem of the company that the person is a part of and, respectively, that determines the purpose and formative ideal).

Based on the criteria previously presented, we conclude that artistic education/instruction (pre-university and university framework) in the Republic of Moldova, if we refer to the whole, certifies aspects that still remain inefficiently valued. The execution of an investigational program, but also of an applicativepractical one, taking into account the factors examined, inevitably leads to the minimising of the distance between the theory and practice of the field targeted. For this purpose, we propose to optimise significantly the process of implementation of the concept of artistic efficiency through the promotion of a progressive view, which resides in the cultivation in practitioners not only of a receptive praxeological style, but also of a formative-innovating praxeology.

In our assertions we derive from the reality that artistic activity differs much from the activities of a person through its ontological specificity, which requires taking into account the apparent opportunities and challenges in the manifestation of the individual potential of a pupil/student, act which is expressed through the transposition of theoretical prescriptions in practical actions undeniably through the presence of emotional reactions, through the experience of logistical projects and maps of the action, meaning not only in waiting certain stimuli coming from the outside, but through the fortification of certain intentions and artistic decision of the pupil/student - subjects of education.

Getting out of such educational-philosophical perspectives, we realize that, for instance, the act of musical perception of the listener is not one of strictly artistic or strictly musical imagination, but one of musical-artistic inspiration. Thus, the activity of the actor of the reception process, connected to this field, is an action with a wide range of influence, with the name of musical-artistic action. Due to these reasons, the notion of "artistic" is not an artificial supplement to the word "musical", but it represents a content with an integrated, unique meaning. Currently, in the environment of theoreticians and practitioners this question is more and more insistently being contoured: What are the requirements and criteria for the efficacy of artistic education? In a certain manner on the statements made on this occasion prof. I. Gagim seeks to expose, who, as basic requirements for the artistic field, highlights the psychopedagogical and musicological foundation of the concept of Musical Education as a distinct and autonomous educational field (direction) of the educational practice and the one of education sciences (I. Gagim, 2004). From the point of view of an efficient artistic education, according to prof. Vl. Pâslaru, the imperative of re-thinking the taxonomy of educational objectives is raised. Thus, it is logical to fundamentally 
research such a requirement in terms of the theory and praxeology of artistic education, the one that derives from the content of the theory-praxis relationship (conceptualization and execution).

Taking into account the previously presented conceptual endeavours, each class, each cycle of subjects matter in the artistic education must emphasize the levels of learning, namely: knowledge of phenomena, (What is this?), appropriation of knowledge and new skills, (What must I undertake?), execution through transfer of the ones appropriated in new situations (How to do it?), assessment/self-assessment of success variables (What is the efficacy of the action?). Musical-artistic activity - designed, roughly, as a specific educational field - oriented towards the increase of the flow of the quality of the action with the same name, as the entire system of artistic education, is regulated by five praxeological principles, which are at the foundation of the reinforcement of the concept of the efficiency of national artistic education and not only.

The principle of the education of proactive personality, which is designed as a managerial self-management and self-improvement instrument, is achieved through: design, decision, option, initiative, independence, intra-independence.

Roughly speaking, proactivity constitutes a defining quality of a person, and has a regulating function for all mental (internal) and behavioural (external) actions, in a continuous dynamic and development. Such a quality is not a simple reaction to internal or external stimuli, but an attitude state, manifested by undertaking own initiatives, an upright quality, developed and achieved by a person consciously. Proactivity is the result of a system of activities directed and promoted based on the choice of operations and of favourable conditions, oriented towards the streamlining of the formative process through interior change. Proactivity does not necessarily have an external expression, but, on the contrary, the recovering value of the action achieved based on this quality, psychical states consist in the stimulation of certain internalised conducts (B.F. Skinner).

The principle of value centering of the artistic action (per activity/action, useful/practical, artistic image, creativity), constitutes the attitude-concept basis of the pupil/student for spiritual-artistic acquisitions and practical executions; it entails the re-sizing of personal, attitude, behavioural factors, responsible for enriching the intimate universe, for the cultivation of a pedagogy of the self.

Psychology certifies that through the property of a person to disseminating from the interior to the exterior purposes are revealed, for the achievement of which the process makes all the efforts in its activity, meaning for whom it prescribes the interior tendencies meant to conquer the peaks of value diversity in fields of high spirituality and creativity. In the context of macrosystemic processes, personality orientation could be qualified as a paradigm gainings-gainings ( $\mathrm{S}$. Covey), which reflects the profit obtained by the pupil/student from the society and which indicates what he/she himself/herself can offer to others. Such a paradigm of orientation of the pupil/student constitutes an ideal model of education. However, in reality, cases contrary to the one described above are 
frequent, namely, when the person seeks to obtain as much profit from social institutions as possible and, at the same time, to consume as little as possible from his/her own resources, who, finally gets the paradigm gainings-failure.

The principle of artistic intro-opening reclaims the establishment of an efficient correlation of individual and artistic environments through the deliberate reception/comprehension/interpretation by teenagers of the artistic message and of the aesthetic essence of the work of art, as well as through the design of personal maps. The intro-opening of the person towards artistic contents is certified by his/her profoundly specified behaviour, expressed through the notion of "intentional attitude of the action" (AIA). This principle comes to increase the efficiency of the process of theoretical and practical knowledge of art based on the fact that the two constituent parties of the principle focus the potential and energies of the pupil/student both through the internalisation and through the externalisation of artistic subjects. The power of the principle mentioned increases proportionally with the increase of the conexional intensity, and it amplifies the processes of the artistic intro-opening of the pupil, which confess about the level of his/her specific performance. The principle intro-opening positively affects not only education agents (teacher/pupil/student), but also the opening dimension of the curriculum to art subjects matter.

The principle of creation and creativity is the edifying condition of building beauty and good and self-creation of the pupil's self; of developing the personal ideal; "conquering" its own intimate universe. Artistic creation and creativity shall be directed so that the word/intonation and everything connected to these communicative factors, to have a permanent purpose to change the paradigm with the tendency to advance from notion-meaning to artistic living. The attention and effort of the pupil/student must be permanently oriented towards individual particularities, constituent of the object of art/painting, music, choreography/ with the artistic complementary, namely the last one constitutes what we used to name through the notions: typical, characteristic, original.

The principle of artistic success prescribes the cause and the results of instruction/education a general and universal nature. Employment in the educational process of success situations, designed and instrumented through the methodological point of view of the previously exposed principles, could contribute, in the most direct manner, to the progressive and efficient progressive and efficient resultativity of the teenager's action, only if and provided that success shall be exposed to examination both as a condition, and as a finality of the artistic education, which entails the aspect of finality, the latter being supported through expectancies, purposes, projects - all forcing us to achieve the consciously and intelligently contoured plans.

Praxeological principles equally with the laws of existence and activation, according to us, are not some amorphous, non-changing postulates, but inherent images of changing events/facts/things, continuously available for reformation, restoration. The touchstone in the approach of the principles presented consists in 
that the efficacy of the operation of each principle is examined from the positions of connecting the theoretical positions/endeavours with its practical effects.

\section{Results}

The results of our research are emergently oriented towards the streamlining of external factors of the educational process and factors that regard human resources, especially, to the efficacy of the musical-artistic action of the pupil/student and to the dynamics of the professional competence of the teaching staff. The two component parts of the educational process can efficiently relate due to the operation in a system of the principle of the education of proactive personality, thus, we sought to design answers to the question What takes places and less to the question How does it take place, in which process the musicalartistic action of the pupil.student and the dynamics of the professional competence of the teaching staff, achieved in line with the principle of proactivity and other four principles, exposed above, may constitute the object of the integration of theoretical endeavours and practical implementations. In order to validate the theoretical assumptions exposed, we carried out the experiment of implementation, in line with several directions.

The first direction applies the level of the proactivity of the pupil/student to the stages of design, organisation and execution of AA in relationship with the interventions of the instructive-educational environment, expressed through the teacher's indications, the authors of the handbook and other managerialpraxeological provisions. The pupils / students of experimental classes / groups (E) are trained in the exercise of execution of a series of items in various types of AA, through which they prove the level of independence and initiative through the manifestation of the competences of advancing the purpose and design of actual steps of execution of AA through:

- description of the actional route (at the level of design);

- highlighting the main and secondary actional steps;

- predictability of possible errors and determination of measures for the removal from the process;

- appointing the nature and character of possible operations to be carried out;

- expectation of unknown;

- highlighting experience landmarks previously acquired;

- determination of the type and content of the action in the initial stage and anticipation of possible interventions along the way;

documentation of internal and external resources employed in the process.

The second direction of the pedagogic experiment regards the study of the pupils'/students' skills in recording behavioural-artistic formative-value paradigms of receiver $\rightarrow$ assessor. Deriving from the experimental concept, it is important to carry out value transfers: from the state of dependence $\rightarrow$ into the state of independence $\rightarrow$ and then into the state of intra-independence, which means tending towards changing the behavioural paradigm, which is directly 
connected to the power to dominate external artistic influences and to efficiently use internal acquisitions.

The third direction of the experimental study is dedicated to the assessment of the effect of opening the pupil/student towards spirit, towards the intimate through the artistic environment. The change of the paradigm is put forward: receiver (reader, listener, observer) $\rightarrow$ interpret-artist.

The fourth direction, in this train of thoughts, is dedicated to the documentation of the degree of efficient connection between the environments: instructive-educational $\leftrightarrow$ individual $\leftrightarrow$ artistic, which reports to those relations: teacher $\leftrightarrow$ pupil/student; pupil/student $\leftrightarrow$ artistic contents. The formulas appointed, obviously lead us to situations-relations: theoretical endeavours $\leftrightarrow$ practical achievements; creative action $\leftrightarrow$ training/change.

The fifth direction of the pedagogic experiment is reduced to proving the role of personal and public success in the streamlining of $\mathrm{AAaE} / \mathrm{S}$ as a fundamental praxeological factor in promoting a qualitative education and training.

The artistic action of the pupil/student (AAaE/S) and the didactic action of the teacher $(\mathrm{ADaP})$ with all the forms, types, constituent elements, nature and specificity of their operation must serve as a fundamental and integrative praxeological object of the experimental program. In the program of the experimental study it is necessary to take into account the following personality qualities:

attitude orientations, which essentially constitute a state of retreat/orientation towards the self;

- autonomous will, complete with full experiences;

- organisational culture;

- level of manifesting independence and initiative;

- sense of value;

- location into success.

In order to carry out a good instructive-educational practice in all fields, but especially in the ones referring to the specificity of manifesting oneself through art, we found the drafting of a set of praxeological model pertinent, which would contribute to the conceptual re-orientation of the practitioner. The models in question are focused on the main laws of efficient operation of the components of the artistic action. Each model includes methods for a good carrying out, reveals exponent positive or negative possibilities of the targeted model, also each model highlights the finalities that can be expected by the actors of the instructiveeducational process.

\section{Model of the relationship: action - qualitative change (ASC)}

Positive opportunities of the model

Argumentations. The pupil/student, being initiated in artistic actions, meditates, lives profound or less profound feelings, but they are hidden from the others. The person is the only observer and assessor of inner phenomena. He/she 
and only he/she accepts or rejects, overrates or underrates the "behaviours" received from the works of art and which could take place, but which, for now, persist in a state of waiting, in a tacit form. The formative-developing influence on the actor of the process does not differ in the least, based on the resources employed in the process, from other forms of behaviour.

- the pupil, especially in artistic and creation fields, needs an opening towards the oneself (refuge towards the inner side) in order to check all the pro and against positions vis-a-vis stimuli coming from the exterior and the interior;

- being a self-observer, the pupil has access to everything that takes place in internal spaces, which are, in many regards, closed to an external observer;

the model of the idealised behaviour constitutes a specific method in the field of artistic creation, which prepares the pupil for the identification of values and the anticipation of musical-artistic events, without him/her carrying out external actions;

- the capitalization of the ASC model, in balanced areas, leads (should lead!) to the musical-artistic independence and intra-independence of the pupil;

- the idealised behavioural model, developed/built inside a person, does not disappear without traces, on the contrary, it is applied strictly in subsequent behaviours, manifested through external actions;

- pupils mastering manifested capacities of the model targeted, usually prove high performances in the field of musical-artistic creation.

Negative opportunities of the model

- the pupils' capacities are left without a field of manifestation or are cloaked and not noticed directly by teachers, colleagues, parents;

idealised musical-artistic behaviours are guided and assessed with great deficiencies by external factors;

- the impossibility of involving the teacher in tacit behavioural processed makes this model left adrift or completely excluded from the educational environment.

- pupils willing to apply into practice the model of the idealized behaviour without a certain situational transfer suffer defeats, are not accepted by the situation.

\section{Model of behavioural change (MSC)}

Argumentations. This model comes in close connection with the first model and entails a behaviour expressed through attitudes coming from the interior of a person and qualified, in an education point of view, as adjectives that invoke a certain quality in the development: disconformity $\rightarrow$ elegance, hesitation $\rightarrow$ consistency, contingence $\rightarrow$ coherence, dilettanteism $\rightarrow$ artistism etc. This model depends, especially, on the learning process, meaning the appropriation of knowledge, skills, forming experiences through imitation. But the main focus is not on the immediate application in life of actual knowledge and skills, but on the pupil's capacities to opt for his/her own views on things, on means of participation, which are forced by internal forces, especially by: thinking, conscience and imagination. MSC entails the option of freedom, which offers the 
pupil the possibility to act in compliance with his/her own interests and purposes, to accomplish the choice. For the musical action, the targeted behaviour constitutes an unmeasurable importance, as it allows the pupil to develop the capacity of option, undertaking responsibilities for the expositions.

\section{Positive opportunities of the MSC:}

- the model stimulates the process of inner organisation of the pupil through the integration of all spiritual elements;

- networking: $\mathrm{P} \leftrightarrow \mathrm{E} \leftrightarrow \mathrm{A}$ (teacher - pupil - art) obtains an open and transparent aspect;

- the pupil is trained in situations of free action with an ample intake to opt;

- the model offers equal chances to the entire sample of pupils/students.

Negative opportunities of the MSC:

- techniques of quantification of qualities of behavioural change are limited;

- The presence of frenator factors, connected to the indifference of practitioners ("why do we need to search the internalness of the pupil", "we could educate the pupils without the examination of attitude contents vis-a-vis their behavioural changes").

\section{Conclusions}

The issue of the networking of educational theory and practice constitutes a key problem of pedagogy. The desideratum of the balance of actions of educational-theoretical environment and educational-practical environment is not to frustrate/trigger traditional action, but to re-orient them towards qualitative change and progress. Currently, the institutionalised educational system does not dispose of sources especially provided for putting into practice theoretical endeavours, only on the path of continuous improvement of teachers in specialised courses. That is why the researcher of nowadays is not indebted to only draft consistent researches, but to also invest their results in the educationalpractical environment.

Factors of positive influencing of the relationship: theory - practice:

the level of pedagogic experience;

- specialization (music and choreography teacher, music and primary grades teacher, primary grades teacher, music and choir teacher, music and musical instrument teacher, etc.);

reported to the level of studies (school of arts/music, high school, faculty);

- creative spirit (proven or possible performances, inferior, average, superior endowment, motivated, oriented activation, "multiple intelligence" (Gardner, 1983).

- individual variables;

- social variables. 


\section{References}

1. BABII, Vladimir, Teoria şi praxiologia educaţiei muzical-artistice, Chişinău, Editura "Elena V.I.", 2010.

2. BABII, Vladimir., BULARGA, T. Succesul artistic al elevilor din perspectiva devenirii personalității social activel Materialele Conferinţei ştiinţifice naţionale cu participare internaţională "Fundamente psihopedagogice ale prevenirii şi combaterii violenţei în sistemul educaţional", 10 octombrie 2014, Univ. Ped. de Stat "Ion Creangă", Fac. Psihologie şi Psihopedagogie Specială, Catedra Psihologie, Chişinău, 2014, p. 214-224. ISBN 978-9975- 115-53-7. 37.015.3(082)=135.1=161.1 F 97.

3. BABII, Vladimir. Praxiologia educaţiei artisticel Educaţia artistică în contextul mediului social-cultural al sec. al XXI-lea, Bălţi, 2014, p. 17-20. ISBN 978-99-75-4227-3-4

4. BABII, Vladimir., Vasile, V. Aptitudinile muzicale între realitate şi ideal/ Educaţia artistică în contextul mediului social-cultural al sec. al XXI-lea, Bălți, 2014, p. 13-17. ISBN 978-99-75- 4227-3-4.

5. BABII, Vladimir. Dinamica gîndirii muzicale / În: Materialele Conferinței științifice internaţionale «Ion Gagim şi universul muzicii». Academia de Științe a Moldovei. Editura Artes, Iaşi., p. 179-183. ISBN 978-606-547-192-4.

6. BABII, Vladimir., BULARGA, Tatiana. Dimensiunea educațională a creativității muzicale in cadrul euroregiunii Siret-Prut-Nistru/ Editia a$\mathrm{X}$-a "Dezvoltarea economico-sociala durabila a euroregiunilor si a zonlor transfrontaliere în cadrul forumului transfrontalier al euroregiunii Siret-PrutNistru", Bălţi, p. 21-22. ISBN 978-606-687-109-9.

7. BULARGA, Tatiana, BABII, Vladimir. The success of artistic education: integration approache. In: Review of artistic education. Artes Publishing House, Iași. ISSN=2069-7554 ISSN-L=2069-7554. Included in CEEOL, EBSCO, Index Copern icus, 2014, p. 250-259.

8. PAȘCA, Eugenia Maria. Dimensiuni ale educației artistice, volumul $V$ Managementul activităţilor muzicale extracurriculare în educaţia formală şi nonformală, Iași: Editura “Artes", 2009, 93 p.

9. PAȘCA, Eugenia Maria. Un posibil traseu al educaţiei muzicale în perioada prenotaţiei, din perspectivă interdisciplinară, Iași: Editura „Artes”, 2006, 309 p. 